Article

\title{
Farmer Field Schools (FFSs): A Tool Empowering Sustainability and Food Security in Peasant Farming Systems in the Nicaraguan Highlands
}

\author{
Esperanza Arnés ${ }^{1, *(\mathbb{D})}$, Carlos G. H. Díaz-Ambrona ${ }^{1}{ }^{(\mathbb{D}}$, Omar Marín-González ${ }^{1}$ and \\ Marta Astier ${ }^{2}$ \\ 1 Dpto. Producción Agraria, Centro de Estudios e Investigación para la Gestión de Riesgos \\ Agrarios y Medioambientales, Universidad Politécnica de Madrid, 28040 Madrid, Spain; \\ carlosgregorio.hernandez@upm.es (C.G.H.D.-A.); o.marin.gon@gmail.com (O.M.-G.) \\ 2 Centro de Investigaciones de Geografía Ambiental, Universidad Nacional Autónoma de México, \\ Campus Morelia, Morelia 581910, Mexico; mastier@ciga.unam.mx \\ * Correspondence: esperanza.arnes@gmail.com or esperanza.arnes@upm.es; Tel.: +34-687-021-339; \\ Fax: +34-915-449-983
}

Received: 5 July 2018; Accepted: 19 August 2018; Published: 24 August 2018

\begin{abstract}
Farmer field schools (FFSs) emerged in response to the gap left by the worldwide decline in agricultural extension services. With time, this methodology has been adapted to specific rural contexts to solve problems related to the sustainability of peasant-farming systems. In this study we draw upon empirical data regarding the peasant-farming system in the Nicaraguan highlands to evaluate whether FFSs have helped communities improve the sustainability of their systems and the food security of their residents using socioeconomic, environmental, and food and nutrition security (FNS) indicators. In order to appreciate the long-term impact, we studied three communities where FFSs were implemented eight, five, and three years ago, respectively, and we included participants and nonparticipants from each community. We found that FFSs have a gradual impact, as there are significant differences between participants and nonparticipants, and it is the community that first implemented FFSs that scores highest. The impact of FFSs is broad and long lasting for indicators related to participation, access to basic services, and conservation of natural resources. Finally, this paper provides evidence that FFSs have the potential to empower farmers; however, more attention needs to be paid to critical indicators like production costs and the use of external inputs in order to scale up their potential in the future.
\end{abstract}

Keywords: peasant-farming systems; food and nutritional security; agricultural extension services; Central America; sustainability indicators

\section{Introduction}

Globalization policies and structural adjustments in Latin America have led to cutbacks in classical extension services and have steadily changed the agricultural landscape [1]. Rural communities and nongovernmental organizations have taken over the roles formerly played by researchers and extension specialists with respect to technology transfer and innovation [2]. This new scenario called upon international cooperation programs to adopt radical and different methodological approaches, which had to be adapted to local socioeconomic, cultural, and agroecological conditions. The challenge in this new scenario was to achieve locally more effective agricultural innovation by applying a new methodology that combined innovation based on extension and training, and participatory learner-centered educational methods [3]. 
Farmer field schools (FFSs) emerged in response to these training and innovation paradigms. FFSs were a participatory means of generating methodological tools to improve decision-making skills and promote local innovation for sustainable agriculture [4]. They were introduced by the Food and Agriculture Organization (FAO) in Indonesia in 1989 but rapidly scaled up and were adopted on all continents. Originally, their main purpose was to deal with specific problems related to pest control and integrated pest management (i.e., planthopper infestation in irrigation rice), but they were also a reaction to rather inefficient "top-down" models of extensionism [5]. Their working methodology was adapted to specific local contexts and needs. This is why FFSs focused on crops and agricultural practices in some regions [6,7], and were more socially oriented in others where they addressed health problems, such as food security $[8,9]$.

Although several participatory extension and research models, like "farmer-to-farmer" programs or local agricultural research committees (CIALS-Spanish acronym), were applied in Latin America, FFSs did not start up until 1997 [10]. Four years later, the Integrated Pest Management Program of Central America (PROMIPAC-Spanish acronym) and FAO introduced FFSs in Nicaragua with the assistance of a number of NGOs, such as CARITAS, FIDER, ADDAC, UNAG, and/or INSFOP-UNICAM [11,12]. In Nicaragua, $41.9 \%$ of the population lives in rural areas (classed as municipalities with a population of less than 2500) [13], and the peasant and family economy accounts for about $50 \%$ of the value of the country's gross agricultural production [14]. From an agroenvironmental viewpoint, this type of farming has a great impact on the conservation of natural resources, sociocultural traditions, and food and nutrition security $[15,16]$. However, the forest area has declined by $13 \%$ over the last 25 years [13], and over $16.6 \%$ of the country's population still suffers from hunger [17].

According to the FAO [18], "food and nutrition security (FNS) exists when all people at all times have physical, social, and economic access to food, which is safe and consumed in sufficient quantity and quality to meet their dietary needs and food preferences, and is supported by an environment of adequate sanitation, health services, and care, allowing for a healthy and active life". To ensure FNS and sustainable agricultural production, Nicaragua's government passed the Food and Nutrition Sovereignty and Security Law in 2009. This law set up an institutional framework for solving the problem of hunger and led to the creation of municipal-level food-security committees. This was conducive to the establishment of FFSs as the backbone of their sustainability and food-security policy.

FFSs were created as short-term tools; however, the effects of FFSs related to improvements in the social, environmental, and economic livelihood of farmers are desirably sustainable. In this sense, the FFSs approach is consistent with other food-assistance programs studied in other countries, where it has been noted as a potential social-innovation tool for empowerment and transformation [19].

Therefore, FFSs mandate more sustained work on the adoption of the proposed technologies and practices. As in any adoption process, FFSs require a good methodological framework together with highly motivated participants and a professional facilitator team [20-22]. FFSs comprise three methodological phases: (i) experiential learner-centered and field-based learning, (ii) observation, experimentation, analysis, and assessment over a timespan to internalize the agroecological and socioecological dynamics, (iii) group and individual decision-making and capacity-building [3].

There is no agreement on how to assess the impact of FFSs. There have been some attempts, mainly focused, however, on measuring farmers' knowledge of pest management [7,22]. Many authors who have been connected with FFS are concerned about the sustainability of FFS impacts; they also agree on the need to assess the longer-term effects of FFSs $[3,5,6]$.

Such FNS-oriented FFSs were implemented by INFOP-UNICAM and the Universidad Politécnica de Madrid (UPM) from 2005 to 2010 at San José de Cusmapa (Nicaragua). The main goals of these FFSs were: (1) improve food and nutrition security; (2) promote techniques to conserve natural resources; and (3) enhance socioeconomic welfare.

Given these identified needs, the main objective of this paper is to evaluate long-term FFS impacts on sustainability and food-security indicators in Nicaraguan mountain peasant communities. Another 
related objective is to evaluate the technology adoption process in terms of type of technology and time to adoption.

\section{Material and Methods}

\subsection{Description of Study Area}

Three communities of San José de Cusmapa (Nicaragua) were selected in this study: Terrero, Llanitos, and Ángel 2. They are surrounded by undulating topography with slopes ranging from $15 \%$ to $20 \%$. The climate is dry-tropical with an average annual rainfall ranging from 1200 to $1400 \mathrm{~mm}$, falling mainly from May to September (five months) and an annual mean temperature of $27^{\circ} \mathrm{C}$ (Figure 1).

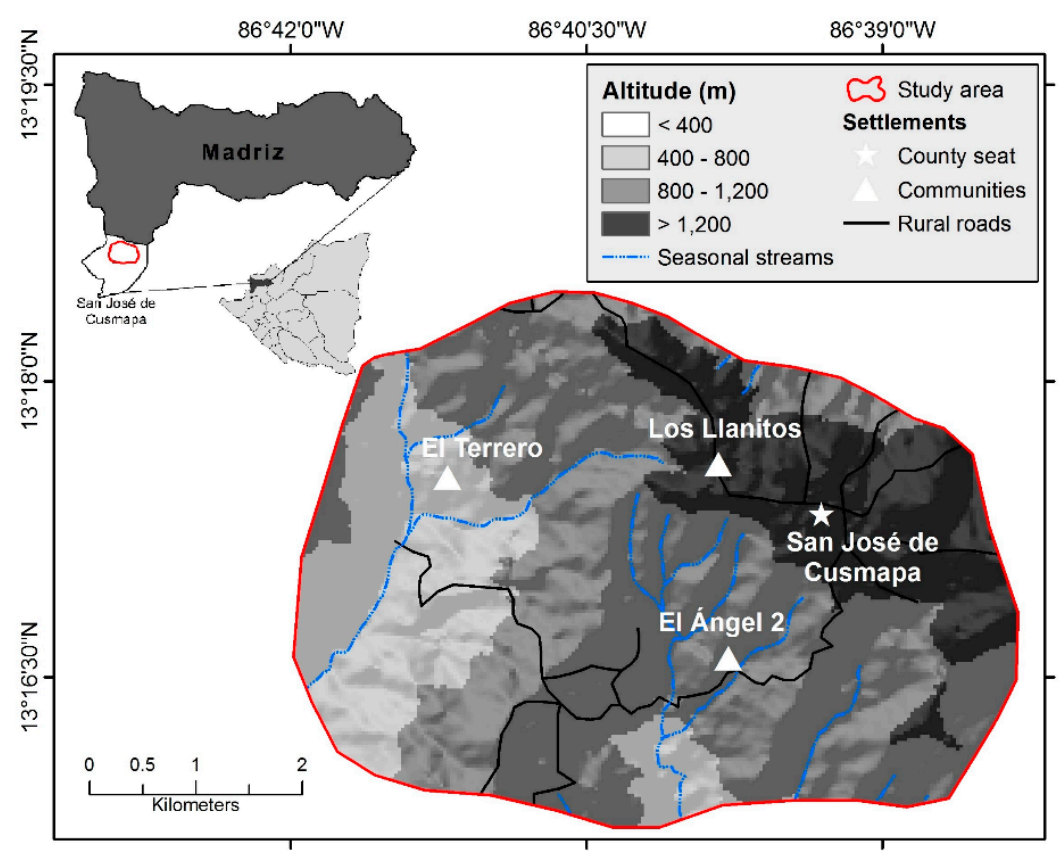

Figure 1. Map of the study area located in Nicaragua (Central America).

Agricultural soils should be used with care given that they are shallow (with a depth of less than $40 \mathrm{~cm}$ ) [23]. Today, land in Nicaragua is mainly used for arable and cattle farming (86\%), and the remaining land area is occupied by forests $(12.5 \%)$ and urban areas $(0.5 \%)$. Poor agricultural practices on sloping lands cause severe soil erosion and landslides [24].

\subsection{Methodological Frameworks and Data Collection}

During the FFSs implementation, more or less all the family members of 20 to 25 households participated in the program. Farmers attended FFSs for eight to nine months, after which local institutions implemented a follow-up process. They met from two to four times a week on a learning plot (temporarily loaned by one of the participants) in order to exchange experiences on crop management based on integrated pest management (IPM), analyze the agroecological system, and discuss soil- and water-conservation techniques. The FFS covers the entire cropping season for the selected crops (mostly grains and vegetables), interspersed with cross-cutting sessions addressing nutrition and hygiene, marketing, and leadership issues [25].

There is no agreement on how to assess the impact of FFSs, not even when integrated pest management is the key issue [3]. However, the complexity of farming-activity forces to the adoption of a holistic approach to sustainability assessment [26]. There are tools that assess sustainability, understood as the ability of a system to maintain and improve its essential functions over time $[27,28]$. In this 
study, we selected the Framework for Assessing the Sustainability of Natural Resource Management Systems (MESMIS, the acronym in Spanish) [29] to evaluate the impact of FFSs on the sustainability and FNS of mountain peasant-farming systems. According to MESMIS, the steps are: (i) characterize communities, including their socioenvironmental context; (ii) identify and derive the critical points and indicators according to FFS-promoted practices and technologies, considering the environmental, socioeconomic, and food/nutrition areas of evaluation; and (iii) develop, measure, and monitor the resulting indicators.

The MESMIS is a systemic framework that, unlike those used by other authors such as Allen [28], highlights the bottom-up approach. In our study, the indicators were agreed with the specialist team and with the farmers. All the indicators were selected through participatory methodologies (Participatory Rural Appraisal (PRA) and community surveys) and were aligned with the objectives of the FFSs. Nevertheless, although obtaining indicators was not the ultimate goal of the study, the measurement and monitoring of these is a key factor in order to give recommendations to all the agents involved [30].

According to this methodological design, three types of results can be analyzed and compared: (a) results for the participants from the three communities, which included farmers that had participated in FFSs in three different years; (b) results for the nonparticipants from these three communities; and (c) results for the two groups-participants and nonparticipants-in each of these communities.

\subsubsection{Data Collection}

Data were collected in 2013, and 67 semistructured household surveys were taken in each of the three communities for participants and nonparticipants. Figure 2 specifies the year in which farmers from the three communities attended FFSs, the time interval elapsed since they completed the FFSs, and the year in which data were collected: Terrero (2005, 8 years), Llanitos (2008, 5 years), and Ángel 2 (2010, 3 years).

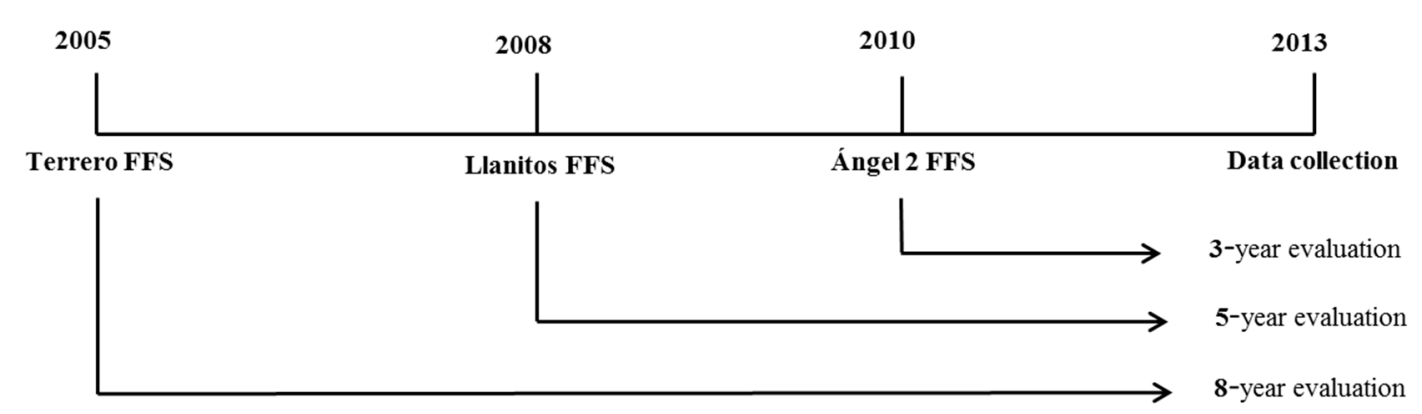

Figure 2. Dates of farmer field school (FFS) implementation and data collection.

We used nonprobability sampling, which requires previous knowledge of the population for sample stratification. This sampling method does not use random selection, and relevant characteristics (quotas) were used to segregate the sample to improve its representativeness. Following Rodriguez Osuna [31], we selected geographical and functional quotas (i.e., FFSs participants and nonparticipants). According to Morales Vallejo [32], the sample size had a confidence level of $95 \%$ and a margin of error of 0.08. It contained 20 out of the 42 households ( 9 participant and 11 nonparticipant families) in Terrero; 24 out of the 64 households ( 15 participant and 9 nonparticipant families) in Llanitos, and 23 out of the 60 households (11 participant and 12 nonparticipant families) in Ángel 2. All indicators were calculated from information derived from the survey, and these data were measured for each household. 


\subsubsection{Characterization of the Communities}

Terrero, Llanitos, and Ángel 2 are three communities in San José de Cusmapa (Nicaragua) and are representative of the mountain-farming systems in the region, where arable and livestock farming are the main economic activities, have risk of soil erosion, and mainly use family labor [33] (Figure 3). The three communities have identical socioeconomic characteristics. Families are usually rather large, with an average of 6.5 persons per household and 2.8 children under 15 years. Due to the steepness of the area, the population is spread across the region (only $19 \%$ is concentrated in the county seat), and farmers spend an average of 40 min walking from their house to their plot [34]. The 7662 inhabitants of San José de Cusmapa are considered Chorotegas, and they occupy a territory officially and traditionally considered indigenous [35]. Although they have foregone some cultural practices in their daily lives and land-management systems, the cultivation of landraces of beans and sorghum, and community resources management are still distinctive of the region [36]. The farmers in this region are peasants that commonly hold diversified and small-scale farms employing family labor and mostly producing subsistence products like maize, beans, and sorghum using intercropping practices [37]. All families work their own land (5.3 ha), but some households rent an average of 0.34 ha.

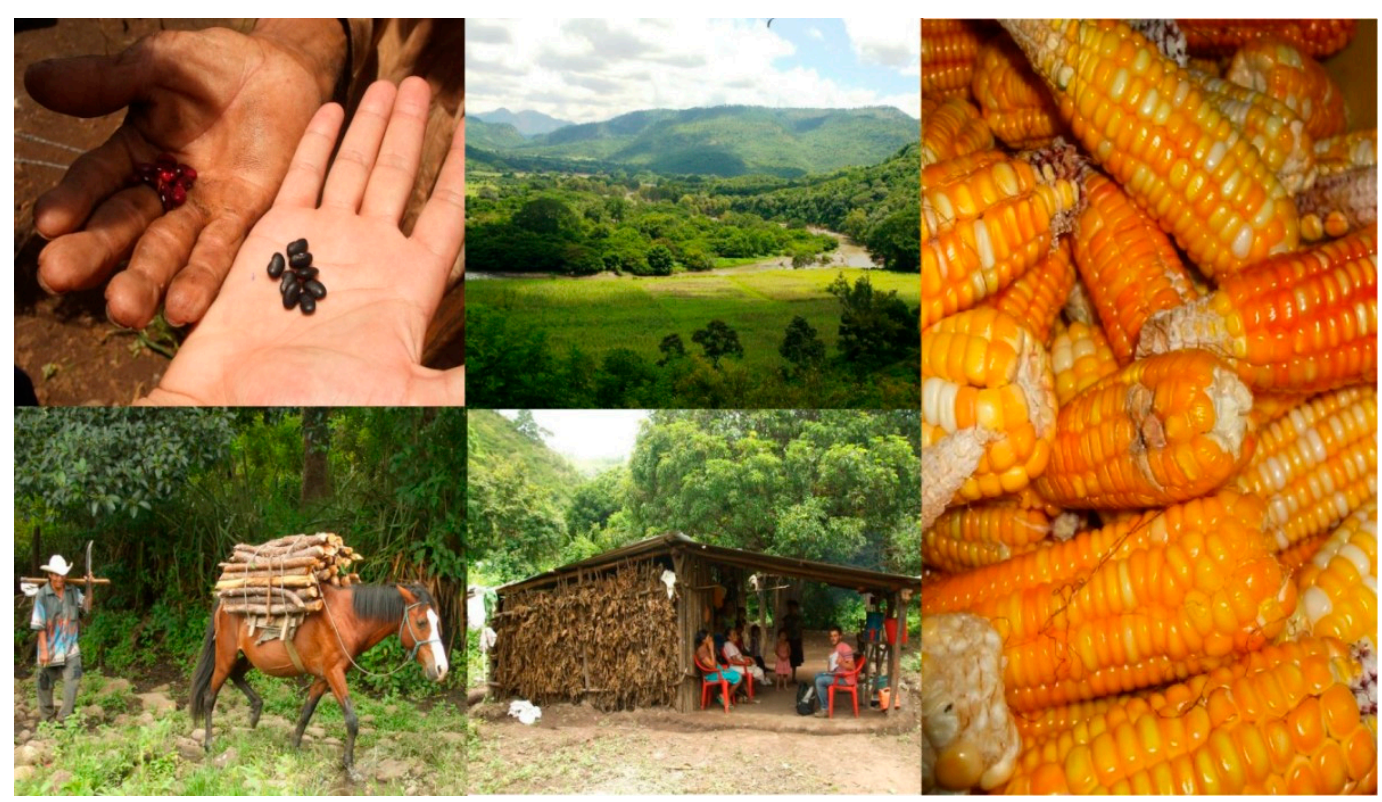

Figure 3. Landscape, crops, and livelihood of mountain peasants in Nicaragua.

There are two growing seasons: the primera season is the first and extends roughly from May to July, and the postrera season runs from August to November. Maize is only grown in the primera season and is sown between May and June using an espeque (a hand-piece built with a metal tip attached to a wooden stick that is used to make the hole). Depending on the community's altitude, maize might be sown in dry soil (hot places) or after the third consecutive rain. Many farmers consider the moon's phases to ensure a better crop-root hold. Beans are grown twice a year. During the primera season, beans are sown together with sorghum, and several days after the maize is sown. The maize stems are bent when the first season of beans is harvested manually at the end of August. The second season of beans is sown in September after the heat wave period (canícula). Maize is harvested manually in November. Postrera beans are harvested in December, and sorghum is harvested in February (seven to eight months after establishment) (Appendix A). Weeding is performed before sowing either with synthetic agrochemicals (glyphosate) or manually. Around 50\% of farmers fertilize by applying from 65 to $130 \mathrm{~kg} \mathrm{ha}^{-1}$ of 18:46:00, 15:15:15, 20:20:20 or urea and from 390 to $520 \mathrm{~kg} \mathrm{ha}^{-1}$ 
of compost. Some farmers apply vermicompost, but it is usually sold. From $17 \%$ to $50 \%$ of farmers conduct pest management by applying from 60 to $500 \mathrm{cc} \mathrm{ha}^{-1}$ of cypermethrin or pyrethroids.

All families raise poultry in their backyards but only $25 \%$ raise larger animals (Figure 3). Most households (83.6\%) depend on seasonal migration (working as coffee harvesters in Honduras for one or two months) as a source of income. This extra income is spent on buying food that they cannot produce, such as salt, sugar, milk, and cloth and agricultural inputs. As a result, any coffee-related external driver (e.g., price fluctuation and rust epidemic) has an impact on these systems by varying the demand for hired labor and therefore the source of supplementary income for many of the households.

\subsubsection{Derivation of Indicators According to FFS Implementation}

The derivation of indicators is part of the evaluation process, and their development is therefore based on the identification of critical points, while always maintaining a direct relationship with the general attributes of sustainability [29]. According to MESMIS, sustainability is defined by seven general attributes: productivity, stability, reliability, resilience, adaptability, equity, and self-reliance. Sustainability attributes are translated into diagnostic criteria that, at the same time, connect indicators with identified critical point of the system (Table 1). As the critical points were identified before the FFS projects were implemented, this study focuses exclusively on the identification, measurement, and monitoring of specific indicators so as to understand the impact of the FFS in each community over time $[25,38]$. The FFSs implemented in our three communities had three main objectives: (1) improve all three dimensions (availability, access, and utilization) of food and nutrition security; (2) promote techniques of natural-resources conservation in order to increase the environmental capital, and (3) enhance socioeconomic welfare. All three objectives are shown in the area of evaluation shown in Table 1. Some 28 indicators were developed and classified by area of evaluation: 13 food-and-nutrition, seven environmental, and 11 socioeconomic indicators. FNS should be considered as a key and holistic issue for peasant-farming-system sustainability, whereas the socioeconomic, institutional, and environmental context are outcomes and drivers that feed the whole system [39].

Table 1. General attributes considered to derive the sustainability indicators in a highland peasant-farming system in San José de Cusmapa (Nicaragua).

\begin{tabular}{|c|c|c|c|c|}
\hline $\begin{array}{l}\text { General } \\
\text { Attributes }\end{array}$ & $\begin{array}{l}\text { Diagnostic } \\
\text { Criteria }\end{array}$ & Critical Point & Indicators & $\begin{array}{c}\text { Area of } \\
\text { Evaluation * }\end{array}$ \\
\hline \multirow{7}{*}{ Productivity } & \multirow{7}{*}{$\begin{array}{c}\text { Productivity and } \\
\text { efficiency }\end{array}$} & \multirow{3}{*}{ Low productivity } & Maize production & FNS \\
\hline & & & Bean production & FNS \\
\hline & & & Sorghum production & FNS \\
\hline & & \multirow{4}{*}{ Low efficiency } & Maize yield & En \\
\hline & & & Bean yield & En \\
\hline & & & Sorghum yield & En \\
\hline & & & Benefit-to-cost ratio & $\mathrm{E}$ \\
\hline \multirow{2}{*}{$\begin{array}{l}\text { Stability } \\
\text { Resilience } \\
\text { Reliability }\end{array}$} & \multirow{2}{*}{ Diversity } & Low agrodiversity & $\begin{array}{c}\text { No. of species grown } \\
\text { No. of animal species bred }\end{array}$ & $\begin{array}{l}\text { En, FNS } \\
\text { E, FNS }\end{array}$ \\
\hline & & $\begin{array}{l}\text { Limited economic } \\
\text { diversity }\end{array}$ & No. of income sources & E, FNS \\
\hline
\end{tabular}


Table 1. Cont.

\begin{tabular}{|c|c|c|c|c|}
\hline $\begin{array}{l}\text { General } \\
\text { Attributes }\end{array}$ & $\begin{array}{l}\text { Diagnostic } \\
\text { Criteria }\end{array}$ & Critical Point & Indicators & $\begin{array}{c}\text { Area of } \\
\text { Evaluation * }\end{array}$ \\
\hline \multirow{8}{*}{ Adaptability } & \multirow{8}{*}{ Capacity of change } & \multirow{3}{*}{ Critical food strategies } & \multirow{3}{*}{$\begin{array}{c}\text { Protein supply } \\
\text { Energy supply } \\
\text { Food strategies in lean } \\
\text { season }\end{array}$} & FNS \\
\hline & & & & FNS \\
\hline & & & & FNS \\
\hline & & \multirow{4}{*}{$\begin{array}{l}\text { Limited technology } \\
\text { adoption (adaptation } \\
\text { mechanism) }\end{array}$} & Erosion control technologies & En \\
\hline & & & $\begin{array}{c}\text { Fertility conservation } \\
\text { technologies }\end{array}$ & En \\
\hline & & & $\begin{array}{l}\text { Integrated pest management } \\
\text { (IPM) }\end{array}$ & En \\
\hline & & & $\begin{array}{l}\text { Level of theoretical } \\
\text { knowledge }\end{array}$ & $\mathrm{S}$ \\
\hline & & $\begin{array}{l}\text { Alternative economic } \\
\text { activities }\end{array}$ & $\begin{array}{l}\text { Off-farm income } \\
\text { representativeness }\end{array}$ & E \\
\hline \multirow{5}{*}{ Equity } & \multirow{5}{*}{ Equity } & Low food equity & $\begin{array}{l}\text { Engel coefficient (proportion } \\
\text { of income spent on food) }\end{array}$ & FNS \\
\hline & & Inappropriate soil use & Forest cover & En \\
\hline & & High production costs & Production costs & $\mathrm{E}$ \\
\hline & & Limited access to basic & Female participation & $S$ \\
\hline & & services & Access to basic services & $\mathrm{S}$ \\
\hline \multirow{5}{*}{ Self-reliance } & \multirow{5}{*}{$\begin{array}{l}\text { Organizational } \\
\text { autonomy and } \\
\text { decision-making } \\
\text { power }\end{array}$} & \multirow{3}{*}{$\begin{array}{l}\text { Irregular food } \\
\text { self-sufficiency }\end{array}$} & Maize self-sufficiency & FNS \\
\hline & & & Bean self-sufficiency & FNS \\
\hline & & & Sorghum self-sufficiency & FNS \\
\hline & & $\begin{array}{l}\text { Poor external input } \\
\text { autonomy }\end{array}$ & External input autonomy & $\mathrm{E}$ \\
\hline & & Low collectiveness & $\begin{array}{l}\text { Participation in local } \\
\text { organization }\end{array}$ & S \\
\hline
\end{tabular}

* FSN: Food and Nutritional Security; En: Environmental; E: Economic; S: Social.

\section{Productivity}

Seven indicators were chosen to evaluate the productivity and efficiency of the systems as follows: (i) maize, (ii) bean, and (iii) sorghum production, all expressed as $\mathrm{kg}$ person ${ }^{-1} \mathrm{year}^{-1}$. These indicators are also measures of food availability, because availability is mostly equivalent to production in subsistence farming systems. We also measured: (iv) maize, (v) bean, and (vi) sorghum yield, all expressed as $\mathrm{Mg} \mathrm{ha}^{-1}$, and (vii) benefit-to-cost ratio (only maize and bean) that establishes the ratio of production cost and opportunity costs (family labor and seed price) to income received from the sale of staple grains at market price. First, the benefit-to-cost ratios of maize and bean were calculated separately. Second, each value was multiplied by the proportion of land used to cultivate each crop in order to yield the overall ratio.

II. Resilience, stability and reliability

Numerous studies document that agrodiversity is linked with the resilience, stability, and reliability of agroecosystems when abrupt and structural changes occur [28,40,41]. According to FAO, [42], resilience is defined as "the ability of a system, community, or society exposed to hazards to resist, absorb, accommodate to, and recover from the effects of a hazard in a timely and efficient manner, including through the preservation and restoration of its essential basic structures and functions". In peasant-farming systems, resilience is maintained through the conservation of base resources and agrodiversity [43-45]. Biological and economic diversification is considered a key strategy for overcoming many of the food emergencies faced by developing countries and rural contexts [46]. Three indicators were selected as follows: (viii) number of agricultural species in cultivation, (ix) number of animal species bred, and (x) number of income sources. As regards the latter indicator, the sale 
of staple grains is only taken into account when farmers state that this activity is a regular source of income because crops are sold as an option and not as a need.

\section{Adaptability}

Adaptability is an attribute of sustainability related to the capacity of change in a system. Adaptability is reinforced through the learning processes that give to the communities the ability to innovate and empower themselves [43-45]. Such capacity of change could be generated by the actual system as a mechanism or strategy of adaptation, or could be induced by external agents through one or more technologies in order to address a particular problem.

On this basis, eight indicators were chosen as follows: (xi) Protein supply is expressed as g protein caput $^{-1}$ day $^{-1}$, and (xii) energy supply as Kcal caput ${ }^{-1}$ day $^{-1}$. Both were calculated as the sum of protein supply or energy supply from daily food intake (maize, bean, sorghum, coffee, rice, and meat) and divided by the number of people living in each household (counting adults and children). (xiii) Food strategies in lean season are expressed as a coefficient ranging from 0 to 1 and are calculated according to farmer survey responses as a qualitative variable (Table 2). Households often adopt several food strategies; the value of the indicator was calculated as the average in these cases.

Table 2. Standardized scale according to farmers' responses w.r.t. quantitative indicators.

\begin{tabular}{|c|c|c|}
\hline Quantitative Indicators & Variable Status & Standardized Scale \\
\hline \multicolumn{3}{|l|}{ Food strategies in lean season } \\
\hline & 1: Do not experience lean season & 1 \\
\hline & 0.75: Eat a food substitute & 0.75 \\
\hline & 0.5: Reduce food intake & 0.5 \\
\hline & 0.25 : Stop eating a foodstuff & 0.25 \\
\hline & 0 : Fast for part of the day & 0 \\
\hline \multicolumn{3}{|l|}{ IPM } \\
\hline & At least 2 IPM with no chemical treatment & 1 \\
\hline & At least 2 IPM with chemical treatment & 0.75 \\
\hline & One IPM with no chemical treatment & 0.5 \\
\hline & One IPM with chemical treatment & 0.25 \\
\hline & Only chemical treatment & 0 \\
\hline & No IPM and no chemical treatment & - \\
\hline \multicolumn{3}{|l|}{ Access to basic services } \\
\hline \multirow{3}{*}{ Water system } & Tap & 1 \\
\hline & Well & 0.5 \\
\hline & River & 0 \\
\hline \multirow{2}{*}{ Electricity system } & Yes & 1 \\
\hline & No & 0 \\
\hline \multirow{3}{*}{ Sanitary system } & Latrine & 1 \\
\hline & Septic tank & 0.5 \\
\hline & No & 0 \\
\hline
\end{tabular}

(xiv) Erosion control technologies were calculated as the sum of the techniques adopted by farmers in order to improve soil retention and conservation. In the surveys, we considered five types of techniques: live barriers (trees or vegetation), dead barriers (stones or wood fences), terraces, dikes, and stubble maintenance (mulch). (xv) Fertility-conservation technologies were calculated as the sum of the techniques adopted in order to improve soil fertility. A total of six techniques were considered: intercropping, rotation, organic manure, stubble incorporation, biofertilizer, and not burn. (xvi) IPM is expressed as a coefficient ranging from 0 to 1 and is calculated according to farmer survey responses (Table 2). We considered five pest-control techniques: traps, natural pesticides or insecticides, 
intercropping, trap crops, and postharvest care. All the participants took a test on their field knowledge before and after FFS implementation.

Farmers should have put most of the issues into practice over years, so the test was repeated in 2013 to reassess their knowledge level. This was measured by the indicator: (xvii) level of theoretical knowledge expressed as a score ranging from 0 to 10 and calculated using the corrected test. There were 20 questions each with three possible choices. Finally, (xviii) off-farm income representativeness is expressed as a percentage and calculated as the proportion of off-farm income over total perceived income.

\section{Equity}

Regarding the measure of equity, five indicators were taken into consideration. (xix) The Engel coefficient is expressed as a percentage and indicates the proportion of income spent on food. It was calculated as the price of the standard food basket in Nicaragua divided by the per capita GDP [47] Forest cover is expressed as a percentage and calculated considering the forest area (i.e., coniferous forest and perennial crops (coffee and fruit trees)) with respect to the total land area per household. (xxi) Production costs are expressed as NIO ha ${ }^{-1}$ including hired labor, land rental, and input costs. (xxii) Female participation is expressed as a percentage and calculated as the proportion of women participating in every FFS. (xxiii) Access to basic services is expressed as a coefficient ranging from 0 to 1 and is calculated according to farmer survey responses (Table 2). It accounts for three types of basic services (water, electricity, and sanitation systems), and the value of the indicator is calculated as the average.

\section{Self-reliance}

Non-self-reliance in a peasant-farming system could cause economic problems if there is no social capital in order to set up control measures or offset the risks faced by farmers who are more dependent on external inputs. The indicators explaining this situation are: (xxiv) maize self-sufficiency, (xxv) bean self-sufficiency, and (xxvi) sorghum self-sufficiency, all expressed as a percentage and calculated as $\mathrm{kg} \mathrm{crop}^{-1}$ produced divided by $\mathrm{kg} \mathrm{crop}^{-1}$ eaten. (xxvii) External input autonomy is expressed as NIO $\mathrm{ha}^{-1}$ and accounts for external agrochemical products (fertilizer, herbicides, and pesticides), as well as improved maize and bean seeds. (xxviii) Participation in local organization is expressed as the number of projects or local associations in which any member of the family is involved.

The impact of FFSs is measured using the indicators listed in Table 1. The list includes direct and indirect indicators. Direct indicators measure the impact based on their real value (i.e., production, protein supply, or participation). Indirect indicators measure the impact according to the level of adoption of management technologies (i.e., erosion, fertility, IPM) or nutrition strategies (i.e., food strategies in lean season, or number of animals). In the same way, there are qualitative and quantitative indicators; therefore, Table 3 shows how the optimal values of each of them has been considered. 
Table 3. Optimal values for the 28 sustainability indicators according to the source literature and survey responses for three communities in San Jose de Cusmapa (Nicaragua).

\begin{tabular}{|c|c|c|c|c|}
\hline Indicators & Units & Optimum & Based on & Source \\
\hline Maize production & $\mathrm{kg}_{\text {caput }}{ }^{-1}$ & 274.00 & Maize consumption in subsistence systems & References $[40,48]$ \\
\hline Bean production & $\mathrm{kg}$ caput $^{-1}$ & 36.00 & National bean consumption in rural areas & Reference [49] \\
\hline Sorghum production & $\mathrm{kg}_{\text {caput }}{ }^{-1}$ & 209.37 & $\begin{array}{l}\text { Maximum production of sorghum harvested } \\
\text { across communities }\end{array}$ & Survey \\
\hline Maize yield & $\mathrm{Mg} \mathrm{ha}^{-1}$ & 1.30 & Average maize yield in Nicaragua & Reference [50] \\
\hline Bean yield & $\mathrm{Mg} \mathrm{ha}^{-1}$ & 0.65 & Average bean yield in Nicaragua & Reference [50] \\
\hline Sorghum yield & $\mathrm{Mg} \mathrm{ha}^{-1}$ & 1.30 & Maximum yield achieved across communities & Survey \\
\hline Benefit-to-cost ratio & coefficient & 2.50 & Farmer and other similar surveys & Reference [40] \\
\hline No. of species grown & number & 12.00 & Farmers & PRA \\
\hline No. of animal species bred & number & 2.50 & Farmers & PRA \\
\hline No. of income sources & number & 5.00 & Farmers & Survey \\
\hline Protein supply & g caput $^{-1}$ day $^{-1}$ & $52.00-70.00$ & Nicaragua's average dietary protein supply & {$[51,52]$} \\
\hline Energy supply & kcal caput $^{-1}$ day $^{-1}$ & $1900-2249$ & Nicaragua's average dietary energy supply & [53] \\
\hline Food strategies in lean season & $*$ & 1.00 & Specialist team and researchers & Table 2 \\
\hline Erosion-control techniques & no. of adopted techniques & 5.00 & Specialist team & Survey \\
\hline Fertility-conservation techniques & no. of adopted techniques & 6.00 & Specialist team & Survey \\
\hline Integrated pest management & $*$ & 1.00 & Specialist team & Table 2 \\
\hline Level of theoretical knowledge & score & 10.00 & Specialist team & Test \\
\hline Off-farm income representativeness & $\%$ & 50.00 & Farmers & Survey \\
\hline Proportion of income spent on food & $\%$ & $\leq 35.20$ & Nicaragua's Engel coefficient & [54] \\
\hline Forest cover & $\%$ & 96.00 & $\%$ of land suitable for forest in SJC & [55] \\
\hline Production costs & $\mathrm{NIO}^{\alpha} \mathrm{ha}^{-1}$ & 813.98 & Minimum value reported in communities & Survey \\
\hline Female participation & $\%$ of women & 50.00 & Farmers and specialist team & PRA \\
\hline Access to basic services & * & 1.00 & Researchers & Table 2 \\
\hline Maize self-sufficiency & $\%$ & 100.00 & Maximum reported value & Survey \\
\hline Bean self-sufficiency & $\%$ & 100.00 & Maximum reported value & Survey \\
\hline Sorghum self-sufficiency & $\%$ & 100.00 & Maximum reported value & Survey \\
\hline External input autonomy & NIO ha ${ }^{-1}$ & 437.93 & Minimum reported value across communities & Survey \\
\hline Participation in local organizations & no. of organizations & 3.00 & Farmers & Survey \\
\hline
\end{tabular}

$\left({ }^{*}\right)$ See Table 2 for further explanation of units; PRA: Participatory Rural Appraisal. SJC: San José de Cusmapa. $(\alpha)$ ISO code for the currency of Nicaragua. 1 NIO $\approx 0.03328$ EUR. 


\subsubsection{Standardization of Indicators}

A range of factors governs the inherent sustainability of any community and any household. On this ground, it is difficult to determine many of these factors and agree upon their optimum ranges [56]. In order to compare the impact of the FFS in each community using sustainability indicators and facilitate the assessment of the three areas of evaluation, the variables were standardized by transforming each indicator to a relative scale of $0-100$, where $100 \%$ is the highest and $0 \%$ is the lowest sustainability value. By adjusting values expressed in different units to a common scale, indicators of different types or complexity can be integrated. Subsequently, the indicators are compared to a likewise standardized optimal value. Baseline values were taken from the source literature and/or agreed on by the evaluation team and farmers (Table 3).

\subsubsection{Statistical Analysis}

Three statistical comparison analyses were conducted (Statgraphics CENTURION vers. XVI). The first two were: (1) among participants from all three communities, and (2) among nonparticipants from all three communities. In both cases, data were subjected to analysis of variance (ANOVA) and means were compared using an LSD test. For the third analysis, we applied a $t$-test to test for the significance of the difference between means for two independent samples (participants and nonparticipants in each of these communities).

\section{Results and Discussion}

FFSs have had an indisputable impact in the community of Terrero. The values of most of the indicators ( 25 out of the 28 indicators) are better for Terrero participants than for the participants from the other communities; the improvement is statistically significant for 13 indicators (Table 4). This confirms the hypothesis that the sustainability and FNS of peasant-farming systems should steadily improve after participation in FFSs, which is the objective of such programs.

On the whole, FFS implementation has, little by little, led to a significant increase in most of the indicators related to peasant-farming-system productivity and efficiency. There has also been a steady and significant, albeit less pronounced, increase in economic diversification. We find that the Terrero participants, who graduated from the FFSs eight years ago, have significantly larger sources of income than Llanitos participants, who graduated five years ago, and Angel 2 participants, who graduated three years ago. More economically diversified households depend less on income from external labor. This shows that livelihood-diversification strategies are correlated with labor-market changes, and increased diversification helps to boost household adaptability [57].

There is a gradual but significant drop in off-farm representativeness. The sources of almost all cash income in the communities of both Ángel 2 and Llanitos are external, 90\% and 77\%, respectively. There has been a quantum leap in Terrero, however, where over $60 \%$ of income comes from the sale of on-farm production. The increase in family purchasing power through on-farm productive resources is confirmation of the FFS-mediated shift from subsistence farming to transitional agriculture, as has already been witnessed in other regions of Latin America and the Caribbean (LAC) [58,59]. The level of theoretical knowledge and access to basic services also undergo a steady and significant improvement (Table 4). 
Table 4. Mean of the 28 indicators for FFS participants and nonparticipants for three mountain peasant-farming communities in Nicaragua.

\begin{tabular}{|c|c|c|c|c|c|c|c|c|c|c|c|c|}
\hline \multirow{3}{*}{$\begin{array}{c}\text { Indicators } \\
\text { Maize production }\left(\mathrm{kg} \mathrm{caput}^{-1}\right)\end{array}$} & \multicolumn{4}{|c|}{ Terrero (8 Years) } & \multicolumn{4}{|c|}{ Llanitos (5 Years) } & \multicolumn{4}{|c|}{ Ángel 2 (3 Years) } \\
\hline & \multicolumn{2}{|c|}{ FFS Participants } & \multicolumn{2}{|c|}{ Nonparticipants } & \multicolumn{2}{|c|}{ FFS Participants } & \multicolumn{2}{|c|}{ Nonparticipants } & \multicolumn{2}{|c|}{ FFS Participants } & \multicolumn{2}{|c|}{ Nonparticipants } \\
\hline & 236.63 & $A^{* *}$ & 133.29 & $a^{* *}$ & 90.11 & B & 104.52 & $\mathrm{a}$ & 119.72 & B & 85.26 & $\mathrm{a}$ \\
\hline Bean production (kg caput ${ }^{-1}$ & 458.14 & $A^{*}$ & 141.56 & $a^{*}$ & 113.12 & B & 122.41 & $\mathrm{a}$ & 130.05 & $\mathrm{~B}$ & 83.00 & a \\
\hline Sorghum production $\left(\mathrm{kg} \mathrm{caput}^{-1}\right)$ & 183.54 & A & 209.37 & $\mathrm{a}$ & 76.76 & B & 35.57 & $\mathrm{~b}$ & 142.44 & $\mathrm{AB}$ & 139.23 & $\mathrm{a}$ \\
\hline Maize yield $\left(\mathrm{Mg} \mathrm{ha}^{-1}\right)$ & 1.40 & $A^{* *}$ & 0.89 & $a^{* *}$ & 0.69 & B & 0.89 & $\mathrm{a}$ & 0.66 & B & 0.57 & $\mathrm{a}$ \\
\hline Bean yield $\left(\mathrm{Mg} \mathrm{ha}^{-1}\right)$ & 1.07 & $\mathrm{~A}$ & 0.84 & $\mathrm{a}$ & 0.57 & B & 0.67 & $\mathrm{a}$ & 0.73 & B & 0.54 & $\mathrm{a}$ \\
\hline Sorghum yield $\left(\mathrm{Mg} \mathrm{ha}^{-1}\right)$ & 1.21 & $\mathrm{~A}$ & 1.30 & a & 0.97 & $\mathrm{~A}$ & 0.86 & $\mathrm{a}$ & 0.80 & $\mathrm{~A}$ & 0.90 & $\mathrm{a}$ \\
\hline Benefit-cost ratio & 1.67 & A & 1.57 & $\mathrm{a}$ & 1.02 & B & 1.13 & $\mathrm{ab}$ & 0.85 & $\mathrm{~B}$ & 0.89 & $\mathrm{~b}$ \\
\hline No. of animal species bred & 1.55 & & 1.27 & & 1.39 & & 1.21 & & 0.82 & & 0.95 & \\
\hline No. of income sources & 5.11 & A & 3.91 & $\mathrm{a}$ & 4.47 & $\mathrm{AB}^{* * *}$ & 2.22 & $b^{* * *}$ & 3.09 & B & 2.58 & $a b$ \\
\hline Protein supply (g protein caput ${ }^{-1}$ day $^{-1}$ ) & 73.82 & $A^{*}$ & 56.74 & $a^{*}$ & 69.76 & $A *$ & 53.82 & $a^{*}$ & 71.78 & $\mathrm{~A}$ & 62.46 & $\mathrm{a}$ \\
\hline Energy supply ( $\mathrm{kcal}$ caput $\left.^{-1} \mathrm{day}^{-1}\right)$ & 2012.17 & A & 1670.33 & $\mathrm{a}$ & 1927.94 & A & 1552.16 & $\mathrm{a}$ & 1937.57 & A & 1604.77 & $\mathrm{a}$ \\
\hline Food strategies in lean season * & 0.67 & $A^{* *}$ & 0.46 & $a^{* *}$ & 0.52 & A & 0.46 & $\mathrm{a}$ & 0.60 & A & 0.50 & $\mathrm{a}$ \\
\hline Erosion control (no. of techniques) & 3.22 & $A^{* *}$ & 2.09 & $a^{* *}$ & 3.40 & $A *$ & 2.22 & $a * *$ & 2.64 & $A^{*}$ & 1.75 & $a *$ \\
\hline Fertility conservation (no. of techniques) & 3.00 & $A^{*}$ & 1.73 & $a^{*}$ & 3.27 & $A^{* *}$ & 2.11 & $a^{* *}$ & 2.55 & A & 1.92 & $\mathrm{a}$ \\
\hline Integrated pest management $*$ & 0.47 & $\mathrm{~A}^{* * *}$ & 0.03 & $a^{* * *}$ & 0.32 & A & 0.16 & $\mathrm{a}$ & 0.58 & $A^{* * *}$ & 0.19 & $a^{* * *}$ \\
\hline Level of theoretical knowledge (score) & 6.87 & A & - & & 5.48 & $\mathrm{AB}$ & - & & 5.40 & B & - & \\
\hline Forest cover $(\%)$ & 53.00 & A & 53.00 & $\mathrm{a}$ & 54.00 & A & 47.00 & a & 47.00 & A & 49.00 & $\mathrm{a}$ \\
\hline Production costs $\left(\mathrm{NIO} \mathrm{ha}{ }^{-1}\right)$ & 2691.73 & $\mathrm{~B}$ & 2099.42 & $\mathrm{a}$ & 1220.46 & A & 813.98 & a & 1399.87 & A & 1165.03 & a \\
\hline Female participation (\% of women) & 32.00 & & - & & 32.26 & & - & & 50.00 & & - & \\
\hline Access to basic services * & 0.96 & $A^{* *}$ & 0.73 & $a^{* *}$ & 0.90 & $A^{*}$ & 0.80 & $a^{*}$ & 0.73 & $\mathrm{~B}^{* *}$ & 0.49 & $b^{* *}$ \\
\hline Corn self-sufficiency (\%) & 95.00 & A & 92.00 & a & 85.00 & A & 82.00 & $\mathrm{a}$ & 87.00 & A & 84.00 & $\mathrm{a}$ \\
\hline Bean self-sufficiency $(\%)$ & 100.00 & $\mathrm{~A}$ & 89.00 & $\mathrm{a}$ & 97.00 & A & 100.00 & $\mathrm{a}$ & 90.00 & $\mathrm{~A}$ & 79.00 & $\mathrm{a}$ \\
\hline Sorghum self-sufficiency $(\%)$ & 89.00 & A & 91.00 & $\mathrm{a}$ & 57.00 & $\mathrm{~B}$ & 75.00 & a & 100.00 & A & 90.00 & $\mathrm{a}$ \\
\hline External input autonomy $\left(\mathrm{NIO} \mathrm{ha}^{-1}\right)$ & 1749.79 & $\mathrm{~B} * *$ & 692.86 & $a^{* *}$ & 892.69 & A & 437.93 & $\mathrm{a}$ & 567.41 & $\mathrm{~A}$ & 656.02 & $\mathrm{a}$ \\
\hline $\begin{array}{l}\text { Participation in local organizations } \\
\text { (no. of organizations) }\end{array}$ & 3.00 & $A^{* * *}$ & 0.91 & $a^{* * *}$ & 1.93 & $\mathrm{~B}^{* * *}$ & 0.78 & $a^{* * *}$ & 1.91 & $\mathrm{~B}^{* * *}$ & 0.58 & $a^{* * *}$ \\
\hline $\mathrm{N}$ (number of households) & 9 & & 11 & & 15 & & 9 & & 11 & & 12 & \\
\hline
\end{tabular}

Capital letters: Significant differences between participants from different communities. Small letters: Significant differences between nonparticipants from different communities. ${ }^{*}$ ) Significant difference at $p<0.1$ between participants and nonparticipants within the same community. (**) Significant difference at $p<0.05$ between participants and nonparticipants within the same community. ${ }^{* * *}$ Significant difference at $p<0.01$ between participants and nonparticipants within the same community. 


\subsection{The Effect of FFSs over Time}

Although FFSs did not affect all indicators equally (not all beneficiaries were equally affected either, but, as we are using means, we consider the performance of each community as a whole), the results provide evidence that the promoted management technologies were successfully and steadily adopted. This means that the FFSs were well-designed and adapted to the context, were manned by a competent team of facilitators and had motivated and willing participants $[3,21,22]$.

There are indicators that show signs of improvement sooner than others, which makes the impact of the FFSs easier to measure. The analysis of variance of the participants and nonparticipants in each of the three communities reveals that there are significant differences for 12 out of the 25 analyzed indicators in the community where the FFSs were first-implemented (Terrero) (Table 4, Figure 4). Significant differences were found for seven out of the 25 indicators in the community where the FFSs were implemented next (Llanitos), whereas they were observed for only four indicators in Ángel 2 (Table 4, Figure 4).

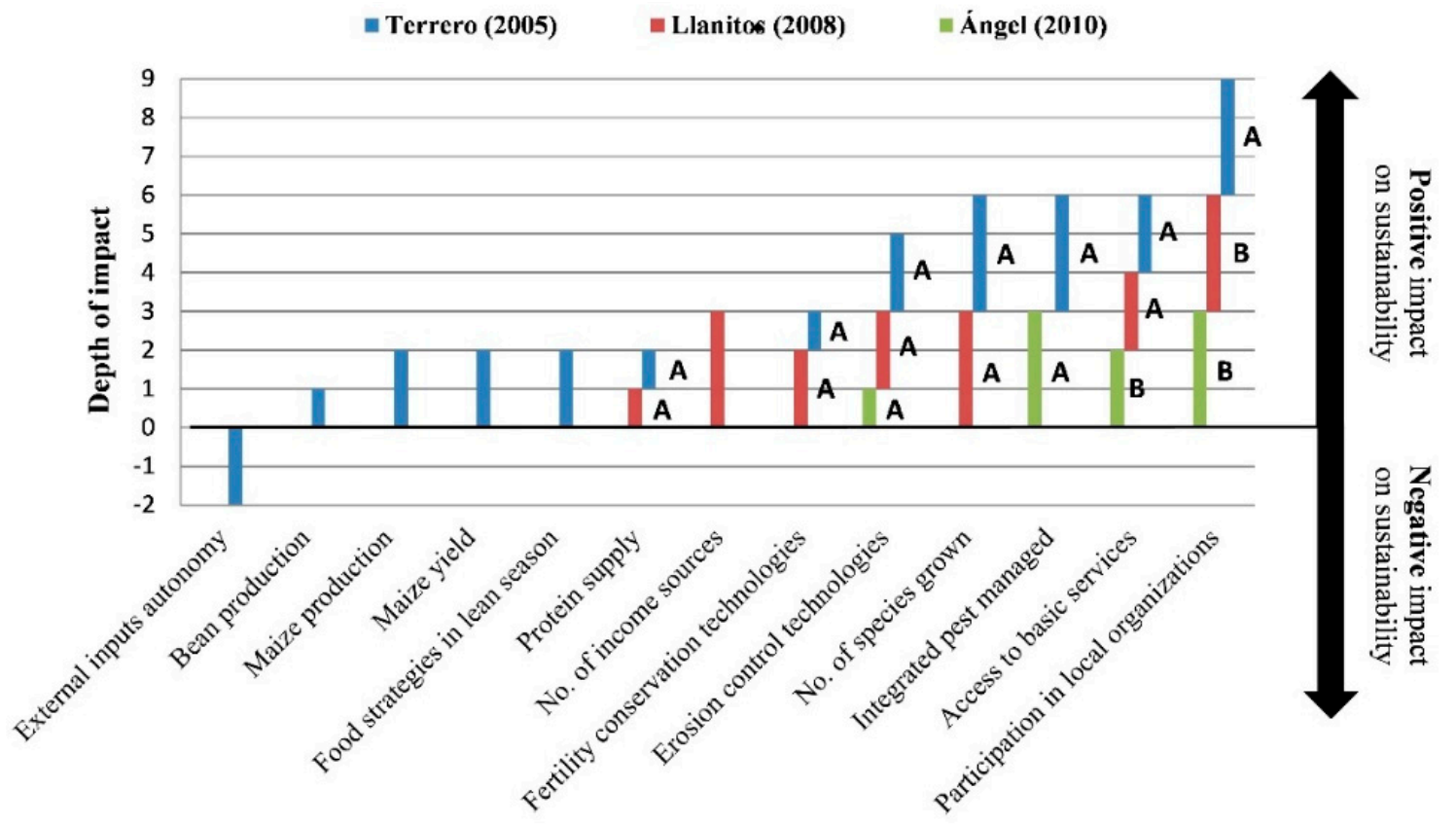

Figure 4. Impact of FFSs in three Nicaraguan mountain peasant-farming communities over time (Legend Figure 4: A and/or B: Significant difference between participants from different communities for each indicator).

Figure 4 plots the 13 indicators that show significant differences between the participants and nonparticipants from the three analyzed communities against depth of impact. For each indicator, the impact is cumulative if it expresses significant differences in two or all three communities. We have calculated the depth of impact of each indicator as the sum of the level of statistical significance, allocating three units when $p<0.01\left(^{* * *}\right)$, two units when $p<0.05\left(^{* *}\right)$, and one unit when $p<0.1\left(^{*}\right)$.

Impact significance can be interpreted taking into account several criteria: (i) breadth, (ii) longevity, and (iii) depth. Breadth is related to the number of communities that exhibit significant differences for a specific indicator. The breadth is high for the participation in local organizations, access to basic services and erosion-control-technologies indicators as there are significant differences in all three communities (Figure 4). Breadth is less for the number of species grown, protein supply, and fertility-conservation-technologies indicators, as there only appears to have been an impact in the communities where the FFSs were implemented longer ago (Terrero and Llanitos). Breadth is very low 
for the external input autonomy, maize production, corn yield, bean production, and food strategies in lean-season indicators, as no significant differences were found until five years after implementation.

Longevity refers to continued significance after a time has elapsed since FFS implementation. This is a potentially cloudy issue, as it is based on ruling out any transfer process within the community. This goes against the aim of FFSs which is to spread their influence as far as possible among participants and nonparticipants. However, allowing for possible bias, the most long-lived indicators are: integrated pest management (it is long-lived in Terrero, not so long-lived in Llanitos, and then long-lived again in Ángel 2), and number of income sources (which is not so enduring in Terrero). We cannot measure longevity of indicators with low breadth.

Finally, the depth is determined by a summation of significance. The indicators with the deepest impact were: participation in local organizations, integrated pest management, number of species grown, and number of income sources as their difference is very significant $\left.{ }^{* * *}\right)$. Depth is moderate for the indicators that express a significant difference of two units $\left.{ }^{* *}\right)$ like maize production or food strategies in lean season, and the depth of impact is considered too low when there is a one-unit significant difference $(*)$, as is the case of protein supply or bean production.

\subsection{Controversies Surrounding FFS Impact}

Despite these signs of overall improvement, the results for two indicators, namely, production costs and external input autonomy, are worse among participants than nonparticipants. There are also significant differences for external input autonomy between Terrero and the other two communities. This indicator is plotted inversely in Figure 4 because it has a negative impact on sustainability.

Analyzing these two indicators, we find that Terrero participants (2005) have 2.2 and 1.9 times more production costs than Llanitos (2008) and Ángel 2 (2010) participants, respectively. Nonetheless, these same farmers produce 3 and 2.25 times more staple grains than their counterparts in the other communities. This reveals that, generally speaking, higher production could be linked to higher costs, highlighting that the adoption of technologies for sustainable farming systems sometimes means making trade-offs [60]. Additionally, the trend for the external input autonomy indicator is the same as for production costs (Table 4). However, this trend does not hold in relative terms (ratio of production costs to external inputs). Terrero participants allocate $65 \%$ of their production costs to external inputs (mostly fertilizers, herbicides, and pesticides), compared to $73 \%$ for Llanitos and $40.5 \%$ for Ángel 2. The fact that the Llanitos community allocates more production costs to external inputs can be explained by its proximity to the county seat $(0.5 \mathrm{~km}$ instead of $7.6 \mathrm{~km}$ for Terrero and $4.4 \mathrm{~km}$ for Angel 2) where these products are easier to acquire.

Looking at the significance of the data, however, we can single out two behaviors: one related to labor and the other related to resources. On one hand, we can assume that FFSs cause community labor to be substituted with external inputs, as is the case in Terrero. This may be prompted by a shortage of available labor or a high opportunity cost caused by there being other better-paid sources of temporary employment, as occurs in other peasant-farming regions of Central America [43,61,62]. On the other hand, it is often necessary to resort to external fertilizers, as the addition of on-farm stubble or vermicompost is not sufficient to achieve acceptable yields for systems with limited resources (soil, slope, climate) [50]. In this respect, as in other LAC regions, the industrial agriculture that is pursued in the region demands manure and organic materials, thereby creating a market. Smallholders take advantage of this market to sell some of their manure, thereby reducing the sources of nitrogen of the mountain agroecosystem [63].

This is a potential weakness of FFSs considering that one of their objectives is to increase productivity through the use of local resources without increasing the use of external inputs [60]. Taking into account the positive results for the indicators related to management practices (erosion-control technologies, fertility-conservation technologies, and integrated pest management) among FFS participants, however, we can conclude that the peasant-farming strategy combines the use of local and external resources. In this respect, it is not unusual to find opposing peasant-farming strategies 
in operation side by side: The same smallholder, region, locality, or household applies communal vs. private access, agricultural systems with low vs. high industrial inputs, or monocultures vs. highly diverse polycultures [64]. This idea is consistent with the findings of other studies that clearly point out that changes in management practices call for trade-offs. It also constitutes further evidence of the complexity of peasant agroecosystems and how hard it is to develop alternative management strategies to improve the overall sustainability of a system [65]. This finding is of utmost importance as it highlights that no 'cure-all' management option exists [43].

Apart from the conflicting peasant-farming scenarios, note also the heterogeneity and differences across households and production systems as other recent studios show [66]. For example, three of the farmers from Terrero could be classed as having embraced the agroecological model in terms of their nutrient-reusing capacity, their soil conservation, and integrated pest-management knowledge, and, consequently, their relative independence from external inputs and activities.

\subsection{The Impact of FFSs on Sustainability as a Whole}

Figure 5 shows three radar charts, each of which corresponds to one of the areas of evaluation: food security, socioeconomic, and environmental (Figure 5, Appendix B). Each chart plots the results for all indicators; each indicator value is compared against the optimal value previously established in Table 2. All indicator values were calculated considering the average indicator value for FFS participants and nonparticipants in each of the three analyzed communities.

From the viewpoint of food and nutrition security, sustainability is represented by 12 indicators (Figure 5, top). Although FNS has three mainstays (availability, access, and utilization), most of the indicators in this field refer to availability, as, in subsistence agriculture, FNS primarily depends on local production [67]. Availability includes the production, self-sufficiency, and diversity indicators. The access component is determined by the food strategies in lean-season and Engel-coefficient indicators. Availability is also evaluated by means of energy supply and protein supply. Terrero (2005) achieves optimal values for more or less six indicators and outperforms the other two communities on five indicators (Figure 5). The staple grains that supply more carbohydrates per unit of consumption are, in decreasing order, maize, sorghum, and rice (3410, 3290, and $\left.3160 \mathrm{kcal} \mathrm{kg}^{-1}\right)$. Unlike rice, all of which is bought, all the communities grow maize and sorghum. Maize self-sufficiency is almost $100 \%$ in Terrero, which explains why it has a higher energy supply than Llanitos and Ángel 2. Sorghum is a different matter, as it is a substitute food for maize. The fact that Ángel 2 is $100 \%$ self-sufficient in sorghum production is positive from the nutritional viewpoint; however, it leads us to think that it is also the community with the biggest maize shortage. This limits food choices or preferences related to the access to certain foods [68,69].

Ángel 2 is the community where the FFSs were implemented most recently. It is near optimal with respect to agroecological diversity where it outperforms Llanitos and Terrero (8.8 and 9.7 crop species, respectively). Although far from optimal (35.2\%), the proportion of total income spent on food (measured by the Engel coefficient) in Ángel 2 is 51.23\%, less than for Terrero (54.06\%) and Llanitos $(62.71 \%)$. This coefficient is usually calculated at national level and assumes that as a nation gets richer, consumers spend more on food, albeit proportionally less than the increase in their income [70]. One consequence of Engel's law is that agriculture's share in the GDP falls as a country becomes wealthier because the demand for food does not grow at the same rate as national revenue [71].

Bean production is optimal for all three communities; although, in quantitative terms, Terrero produces 2.4 and 2.7 times more than Llanitos and Ángel 2, respectively. In peasant-farming contexts, beans are a key source of protein; they account for $21.8 \%$ of total protein intake, whereas only $4 \%$ to $6 \%$ of protein consumed comes from meat. There are no protein deficiencies in any of the communities, but significant differences were observed between participants and nonparticipants in Terrero and Llanitos (Table 4, Figure 4). This confirms that the FFS action has promoted the adoption of healthier eating habits. 

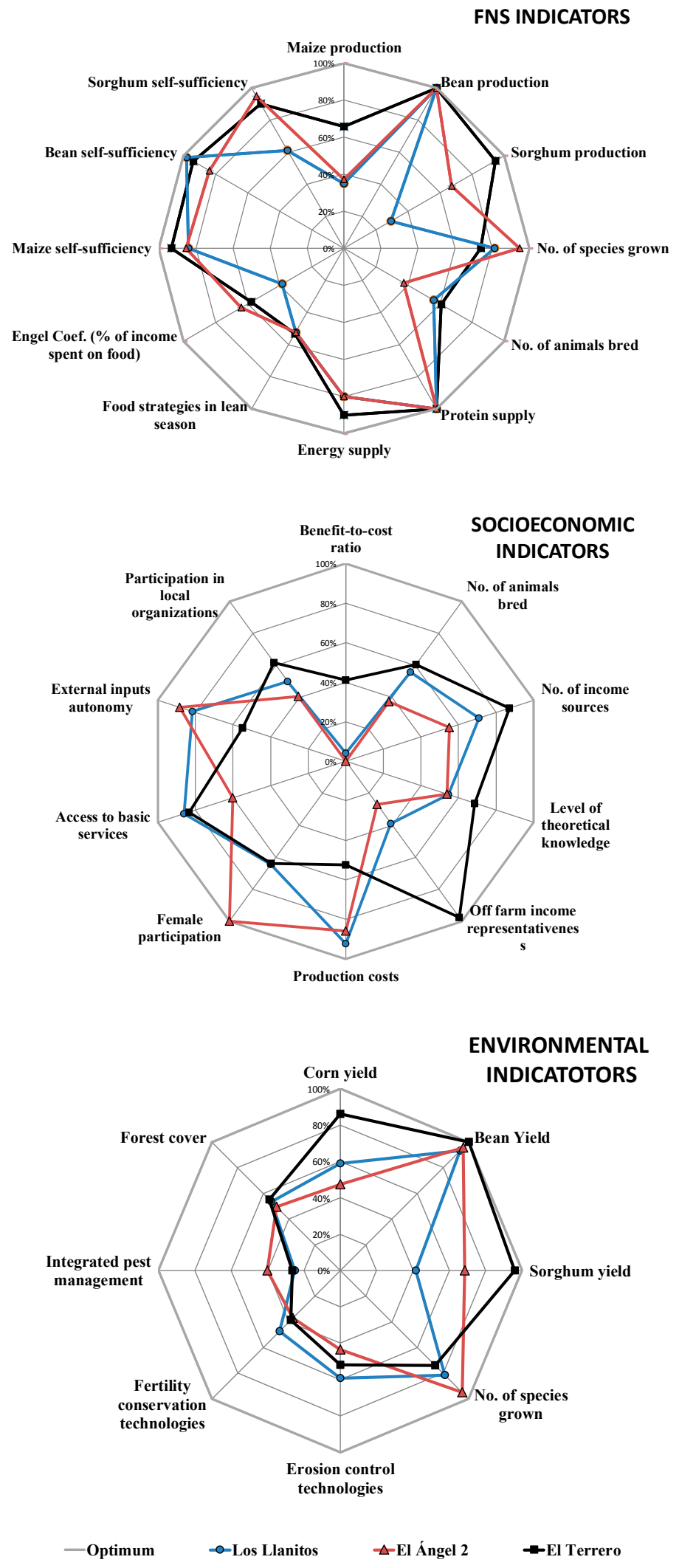

Figure 5. Sustainability levels of the three communities in the Nicaraguan highlands assessed using 28 indicators and divided by areas of evaluation defined according to FFS objectives. 
From an environmental viewpoint, sustainability is represented by eight indicators (Figure 5, below). This chart again features the number of species-grown indicator, as agrodiversity has an impact not only on food diversification but also on agroecosystem diversity; this may have a more important effects in the long term. The other indicators are associated with staple grain yields and the adoption of technologies related to environmental conservation. Terrero achieves near optimal maize, bean, and sorghum yields $(86 \%, 100 \%$, and $96 \%)$. However, the values of the other indicators are quite consistent across communities and well below the optimal levels. This is linked to the significant differences between FFS participants and nonparticipants for indicators associated with the adoption of technologies for natural resources conservation, such as erosion control, soil fertility conservation and integrated pest management (Table 4). We found that FFS participants are quick to adopt these types of technologies but there is no technology transfer to the other farmers in any of these communities. For example, the values for the adoption of integrated pest management among nonparticipants are, predictably, very low: Terrero (3\%), Llanitos (16\%), and Ángel 2 (19\%).

From the socioeconomic viewpoint, sustainability is represented by 10 indicators (Figure 5, center). The values of the economic indicators are better for the Terrero community. Although production costs for Terrero are greater than for Llanitos and Ángel 2 and farmers in this community are more dependent on external inputs, it has a higher agricultural benefit-to-cost ratio (1.61). This is quite a moderate production-efficiency value taking into account that the optimum for such systems is around 2.5 [40]; however, it is much higher than the ratio for Llanitos (1.06) and the inefficiency of Ángel 2 (0.87).

The communities differ most as to the social indicators. Again, Terrero is the community that scores highest for all social indicators, except female participation in FFSs, where women account for $32 \%$ of all participants against the $50 \%$, and thus optimal, female participation in Angel 2. Terrero residents have access to a greater number of basic services (identical to the population of Llanitos). And it is they that also proved to have more theoretical knowledge in the theory test on what they had learned at the FFSs, even though Terrero was the first community to participate. This higher test score confirms continued practical implementation of much of what they had learned at the FFS.

The indicator related to participation in local organizations shows how, as time goes by, the breadth, depth, and longevity of participation by FFS participants steadily increases. This is not an isolated phenomenon, as there is a tradition of cooperativism in Nicaraguan communities promoted by the establishment of rural community associations and organizations, such as radiophonic schools for popular education. In this respect, the FFSs have not only encouraged their participants to participate in external programs but also empowered participants to take an active role in their development and lead their own initiatives. The significant difference between FFS participants and nonparticipants for this indicator begs the question of whether FFSs are having an impact on most nonparticipant households or, contrariwise, are indirectly promoting inequity within communities. Do participant families have greater decision-making power within local organizations leading to other families being excluded from participation?

FFSs are an extremely valuable tool provided that they are carried out by partners who expertly contextualize the regional problems, know how to align the political directives and their own strategies for the good of the people for whom they are working. A holistic approach, which takes on board social education, is the key to the success of any more technical action. It is important, however, not to neglect to analyze any resulting inequities together with the identified trade-offs.

\section{Conclusions}

Over the last decades, sustainability and food and nutritional security have been the subjects of considerable academic interest and debate in both conceptual and methodological terms. The persistence of high levels of environmental degradation and food insecurity in many regions has led to new initiatives aiming to revitalize peasant agriculture and to renewed discussions on the role of sustainability as an engine of development, environmental conservation, and poverty alleviation. 
This paper has evaluated the performance of a renew extension service called Farmer Field School in three rural communities of the Nicaraguan highlands that emerged out of NGO efforts. Thanks to the steps marked by the MESMIS framework, which led to the identification of 28 indicators, the analysis has shown that FFSs are valuable tools that promote the sustainability and food security of farm households over time.

The results for many of the evaluated sustainability indicators improved as time elapsed since FFS implementation. The comparison between the nonparticipants from all three communities showed that some technology transfer has taken place. This finding highlights that FFSs, like other participatory models of extension and research such as farmer-to-farmer programs, are achieving their objective with regard to technology dissemination and transfer among peasants.

This study demonstrates the potential of FFSs, but more attention will have to be paid to critical indicators in order to scale up their potential in the future. We observed a direct relationship between the increase in agricultural production and the use of external inputs, which is a critical point for sustainable ideals. Production efficiency would also need to be improved (benefit-to-cost ratio values are very low) by boosting the use of fertility-improvement and soil-erosion technologies. Maize production is still at critical levels in communities where the FFSs were more recently implemented; however, this does not translate to deficient energy intakes, as residents consume other substitute products like sorghum or rice on which they spend part of their income.

Ultimately, the real success of FFSs is as social transformers by empowering the participants to promote their own development. Farmers will invest in and implement sustainable technologies and farm practices if they expect the investment to be profitable, if they have the right education, information, and motivation, and if government policies set clear goals related to other common goods. We cannot ignore the fact, however, that farmers who attend FFSs are not a product of a random phenomenon but the cause of self-selection based on their pre-existing conditions and motivation. Future studies might monitor the evolution of these and other mountain communities to check whether the effect of the FFSs is sustained over time and whether their positive effects, mainly FNS transfer and improvement, can be accelerated and extrapolated. This would confirm the fact that these methodologies facilitate the shift from subsistence farming to sustainable family farming.

Author Contributions: E.A. and C.G.H.D.-A. developed the concept. E.A. designed and performed experiments, analyzed data and prepared the manuscript. M.A. reinforced the manuscript. E.A. and O.M.-G. tested the research strategy and conducted questionnaire interviews. M.A. and C.G.H.D.-A. supervised the research.

Funding: This research was supported by the Universidad Politécnica de Madrid under the program "Comunidades Rurales del Mileno".

Acknowledgments: We are very grateful to all of the Nicaraguan families who participated in this work for their technical knowledge and human values. Thanks to the INSFOP-UNICM team, especially to Ángela Centeno, who provided us with an excellent logistical operation in the field and with essential feedback. We also thank Ángel David Flores Domínguez (CIGA) for technical support.

Conflicts of Interest: The authors declare no conflict of interest. The funders had no role in the design of the study; in the collection, analyses, or interpretation of data; in the writing of the manuscript, and in the decision to publish the results. 


\section{Appendix A. Crops Calendar}

Table A1. Maize cultivation calendar in San José de Cusmapa (Nicaragua).

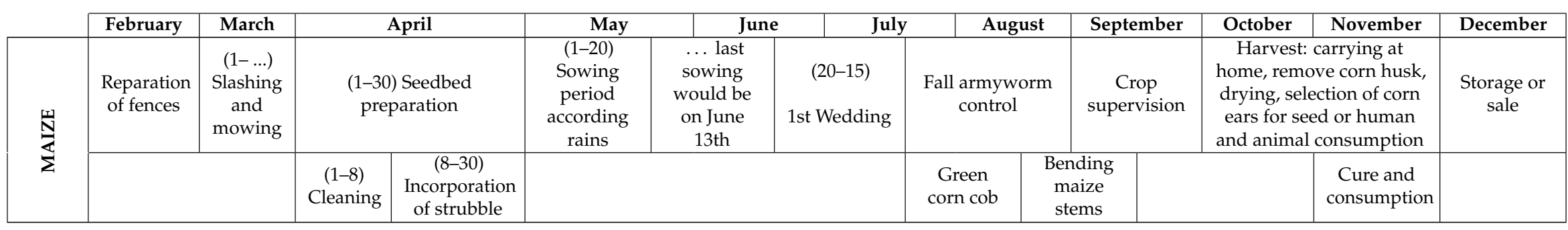

Table A2. Sorghum cultivation calendar in San José de Cusmapa (Nicaragua).

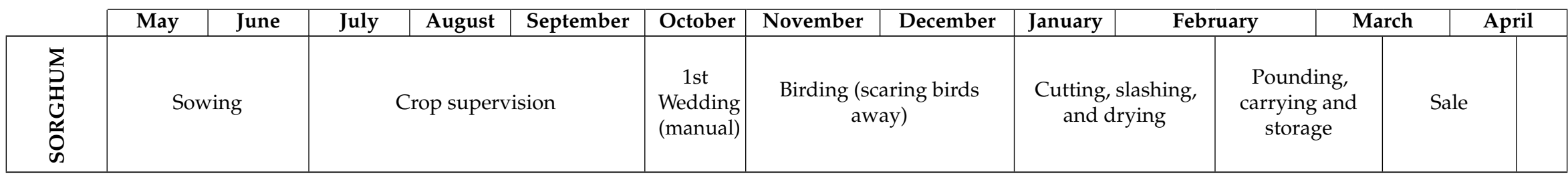

Table A3. Bean cultivation calendar in San José de Cusmapa (Nicaragua).

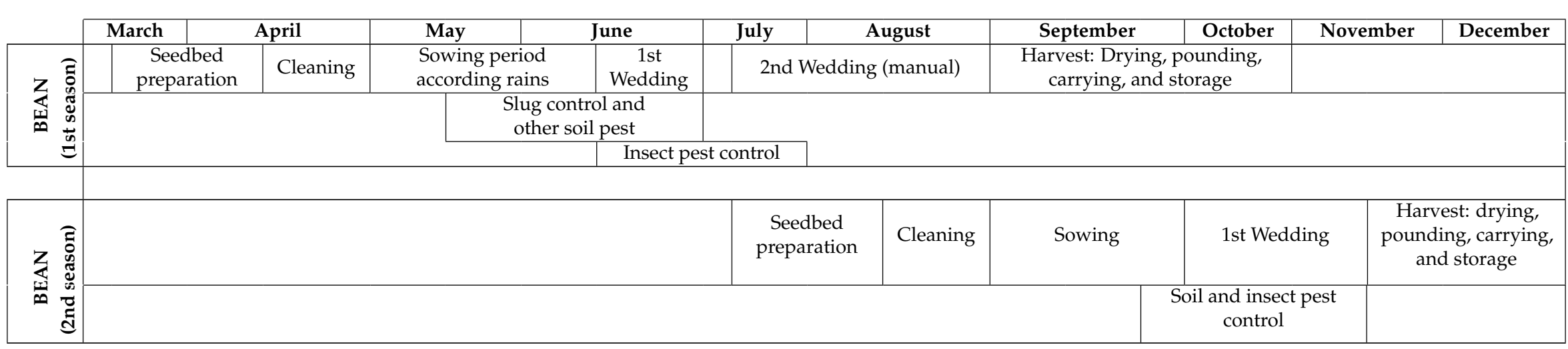




\section{Appendix B}

Table A4. Absolute and (standardized) average values of the 28 indicators that analyze, by area of evaluation, the performance of the FFSs in three communities of San José de Cusmapa (Nicaragua).

\begin{tabular}{|c|c|c|c|c|c|c|c|c|c|c|c|c|}
\hline $\begin{array}{c}\text { FNS } \\
\text { Indicators }\end{array}$ & $\begin{array}{c}\text { Maize } \\
\text { Production } \\
\left.\text { (kg Caput }^{-1}\right)\end{array}$ & $\begin{array}{c}\text { Bean } \\
\text { Production } \\
\left.\text { (kg Caput }^{-1}\right)\end{array}$ & $\begin{array}{c}\text { Sorghum } \\
\text { Production } \\
\text { (kg Caput }^{-1} \text { ) }\end{array}$ & $\begin{array}{l}\text { No. of Species } \\
\text { Grown (\#) }\end{array}$ & $\begin{array}{c}\text { No. of } \\
\text { Animals Bred } \\
\text { (\#) }\end{array}$ & $\begin{array}{l}\text { Protein Supply } \\
\text { (g Caput }^{-1} \\
\text { Day }^{-1} \text { ) }\end{array}$ & $\begin{array}{c}\text { Energy Supply } \\
\text { (kcal }^{\text {Ekat }} \\
\text { Caput }^{-1} \text { Day }^{-1} \text { ) }\end{array}$ & $\begin{array}{c}\text { Food } \\
\text { Strategies in } \\
\text { Lean Season } \\
\text { (Coef.) }\end{array}$ & $\begin{array}{l}\text { Engel Coef. } \\
\text { (\% of Income } \\
\text { Spent on } \\
\text { Food) }\end{array}$ & $\begin{array}{l}\text { Maize Self- } \\
\text { Sufficiency } \\
(\%)\end{array}$ & $\begin{array}{c}\text { Bean Self- } \\
\text { Sufficiency } \\
(\%)\end{array}$ & $\begin{array}{c}\text { Sorghum } \\
\text { Self- } \\
\text { Sufficiency } \\
(\%)\end{array}$ \\
\hline Optimum & $274.00(100 \%)$ & $36.00(100 \%)$ & $209.37(100 \%)$ & $\geq 12.00(100 \%)$ & $\geq 2.5(100 \%)$ & $52-70(100 \%)$ & $1900-2440(100 \%)$ & $1.00(100 \%)$ & $\leq 35.20(100 \%)$ & $100 \%$ & $100 \%$ & $100 \%$ \\
\hline El Terrero & $179.79(66 \%)$ & $284.02(100 \%)$ & $197.75(94 \%)$ & $8.85(74 \%)$ & $1.51(61 \%)$ & $64.43(100 \%)$ & $1824(90 \%)$ & $0.53(53 \%)$ & $54.06(58 \%)$ & $93 \%$ & $94 \%$ & $90 \%$ \\
\hline Los Llanitos & $95.52(35 \%)$ & $116.60(100 \%)$ & $61.31(29 \%)$ & $9.75(81 \%)$ & $1.40(56 \%)$ & $63.78(100 \%)$ & $1787(80 \%)$ & $0.52(52 \%)$ & $62.72(39 \%)$ & $84 \%$ & $98 \%$ & $61 \%$ \\
\hline El Ángel 2 & $101.74(37 \%)$ & $105.74(100 \%)$ & $140.77(67 \%)$ & $11.40(95 \%)$ & $0.93(37 \%)$ & $66.92(100 \%)$ & $1764(80 \%)$ & $0.52(52 \%)$ & $51.23(64 \%)$ & $85 \%$ & $84 \%$ & $95 \%$ \\
\hline $\begin{array}{l}\text { Socioeconimic } \\
\text { Indicators }\end{array}$ & $\begin{array}{l}\text { Benefit-to-cost } \\
\text { ratio (coef.) }\end{array}$ & $\begin{array}{c}\text { No. of animals } \\
\text { bred (\#) }\end{array}$ & $\begin{array}{l}\text { No. of income } \\
\text { sources (\#) }\end{array}$ & $\begin{array}{c}\text { Level of } \\
\text { theoretical } \\
\text { knowledge } \\
\text { (score) }\end{array}$ & $\begin{array}{c}\text { Off-farm } \\
\text { income } \\
\text { representativeness } \\
(\%)\end{array}$ & $\begin{array}{c}\text { Production costs } \\
\mathrm{s} \quad\left(\mathrm{NIO} \mathrm{ha}^{-1}\right)\end{array}$ & $\begin{array}{c}\text { Female } \\
\text { participation (\% } \\
\text { of women) }\end{array}$ & $\begin{array}{l}\text { Access to } \\
\text { basic services } \\
\text { (coef.) }\end{array}$ & $\begin{array}{c}\text { External } \\
\text { inputs } \\
\text { autonomy } \\
\left(\mathrm{NIO} \mathrm{ha}^{-1}\right)\end{array}$ & $\begin{array}{c}\text { Participation } \\
\text { in local } \\
\text { organizations } \\
(\#)\end{array}$ & & \\
\hline Optimum & $\geq 2.50(100 \%)$ & $\geq 2.50(100 \%)$ & $5.00(100 \%)$ & $10.00(100 \%)$ & $50.00(100 \%)$ & $813.98(100 \%)$ & $50.00(100 \%)$ & $1.00(100 \%)$ & $437.93(100 \%)$ & $3.00(100 \%)$ & & \\
\hline El Terrero & $1.61(41 \%)$ & $1.51(61 \%)$ & $4.45(87 \%)$ & $6.87(69 \%)$ & $48.82(98 \%)$ & $2365.96(52 \%)$ & $32.00(64 \%)$ & $0.83(83 \%)$ & $1168.48(55 \%)$ & $1.85(62 \%)$ & & \\
\hline Los Llanitos & $1.06(4 \%)$ & $1.40(56 \%)$ & $3.62(71 \%)$ & $5.48(55 \%)$ & $80.51(39 \%)$ & $1068.03(92 \%)$ & $32.25(65 \%)$ & $0.86(86 \%)$ & $722.15(82 \%)$ & $1.50(50 \%)$ & & \\
\hline El Ángel 2 & $0.87(0 \%)$ & $0.93(37 \%)$ & $2.83(55 \%)$ & $5.40(54 \%)$ & $86.46(27 \%)$ & $1277.34(86 \%)$ & $50.00(100 \%)$ & $0.60(60 \%)$ & $613.64(88 \%)$ & $1.22(41 \%)$ & & \\
\hline $\begin{array}{l}\text { Environmental } \\
\text { Indicators }\end{array}$ & $\begin{array}{l}\text { Corn yield } \\
\left(\mathrm{Mg} \mathrm{ha}^{-1}\right)\end{array}$ & $\begin{array}{l}\text { Bean yield } \\
\left(\text { Mg ha }^{-1}\right)\end{array}$ & $\begin{array}{l}\text { Sorghum yield } \\
\left(\mathrm{Mg} \mathrm{ha}^{-1}\right)\end{array}$ & $\begin{array}{l}\text { No. of species } \\
\text { grown (\#) }\end{array}$ & $\begin{array}{l}\text { Erosion control } \\
\text { technologies (\#) }\end{array}$ & $\begin{array}{c}\text { Fertility } \\
\text { conservation } \\
\text { technologies (\#) }\end{array}$ & $\begin{array}{c}\text { Integrated pest } \\
\text { management } \\
\text { (coef.) }\end{array}$ & $\begin{array}{c}\text { Forest cover } \\
(\%)\end{array}$ & & & & \\
\hline Optimum & $1.30(100 \%)$ & $0.65(100 \%)$ & $1.30(100 \%)$ & $\geq 12(100 \%)$ & $5.00(100 \%)$ & $6.00(100 \%)$ & $1.00(100 \%)$ & $96.00(100 \%)$ & & & & \\
\hline El Terrero & $1.12(86 \%)$ & $0.94(100 \%)$ & $1.26(96 \%)$ & $8.85(74 \%)$ & $2.60(52 \%)$ & $2.3(38 \%)$ & $0.26(26 \%)$ & $53.12(55 \%)$ & & & & \\
\hline Los Llanitos & $0.71(59 \%)$ & $0.61(93 \%)$ & $0.54(42 \%)$ & $9.75(81 \%)$ & $2.96(59 \%)$ & $2.83(47 \%)$ & $0.25(25 \%)$ & $51.52(54 \%)$ & & & & \\
\hline El Ángel 2 & $0.62(47 \%)$ & $0.63(96 \%)$ & $0.89(68 \%)$ & $11.40(95 \%)$ & $2.17(43 \%)$ & $2.22(37 \%)$ & $0.40(40 \%)$ & $47.70(50 \%)$ & & & & \\
\hline
\end{tabular}




\section{References}

1. Settle, W.; Garba, M.H. Sustainable crop production intensification in the Senegal and Niger River basins of francophone West Africa. Int. J. Agric. Sustain. 2011, 9, 171-185. [CrossRef]

2. Braun, A.; Duveskog, D. The Farmer Field School approach: History, Global Assessment and Success Stories; IFAD Rural Poverty Report; International Fund for Agricultural Development (IFAD): Rome, Italy, 2008.

3. Braun, A.; Jiggins, J.; Röling, N.; van den Berg, H.; Snijders, P. A Global Survey and Review of Farmer Field School Experiences; International Livestock Research Institute: Wageningen, The Netherlands, 2006.

4. Braun, A.R.; Thiele, G.; Fernández, M. Agricultural research committees: Complementary platforms for integrated decision-making in sustainable agriculture. In Agricultural Research and Extension Network; Overseas Development Institute: London, UK, 2000. Available online: http://laolink.org/Literature/ agrenpaper_105.pdf (accessed on 16 November 2015).

5. Bentley, J.W. Impact of IPM Extension for Smallholders Farmers in the Tropics. In Integrated Pest Management: Dissemination and Impact; Peshin, R., Dhawan, A.K., Eds.; Springer Science + Bussiness Media B.V.: Berlin, Germany, 2009; pp. 333-346, ISBN 978-1-4020-8989-3.

6. Godtland, E.M.; Sadoulet, E.; De Janvry, A.; Murgai, R.; Ortiz, O. The Impact of Farmer Field Schools on Knowledge and Productivity: A Study of Potato Farmers in the Peruvian Andes. Econ. Dev. Cult. Chang. 2004, 53, 63-92. [CrossRef]

7. Van der Berg, H.; Jiggins, J. Investing in Farmers-The Impacts of Farmer Field Schools in Relation to Integrated Pest Management. World Dev. 2007, 36, 2103-2106. [CrossRef]

8. De Schutter, O.; Vanloqueren, G. The New Green Revolution: How Twenty-First-Century Science Can Feed the World. Solut. J. 2011, 2, 1-12.

9. Callens, K.; Gallagher, K.D. Incorporating nutrition in farmer field schools. Food Nutr. Agric. 2003, 32, $62-68$.

10. Sherwood, S.; Nelson, R.; Thiele, G.; Ortiz, O. Farmer Field Schools in Potato: A New Platform for Participatory Training and Research in the Andes; ILEIA: Quito, Ecuador, 2000.

11. Gottret, M.V.; Córdoba, M.D. Políticas y procesos de innovación tecnológica con productores de pequeña escala en Honduras y Nicaragua. El caso del programa de manejo integrado de plagas en Centroamérica (PROMIPAC). 2004. Available online: https://core.ac.uk/download/pdf/48031885.pdf (accessed on 16 November 2015).

12. Ortiz, R.; Ruano, S.; Monterrey, J. Análisis Comparativo Entre Diferentes Modalidades y Metodologías de Extensión Agropecuaria y Forestal en Nicaragua. Una Propuesta de Lineamientos para la Política Sectorial en el tema de Extensión Agrícola; FUNICA: Managua, Nicaragua, 2006.

13. FAO. FAO Statistical Pocketbook. World Food and Agriculture; FAO: Rome, Italy, 2015.

14. García Ruiz, A. Programas de Alimentación Escolar y Compras de Agricultura Familiar Campesina en los Programas Sociales de Asistencia Alimentaria; FAO: Managua, Nicaragua, 2011.

15. Clapp, R.A. Regions of Refuge and the Agrarian Question: Peasant Agriculture and Plantation Forestry in Chilean Araucania. World Dev. 1998, 26, 571-589. [CrossRef]

16. Altieri, M.A.; Nicholls, C.I. Agroecología: Teoría y Práctica para una Agricultura Sustentable; PNUMA, Ed.; Textos Básicos para la Formación Ambiental: México, 2000.

17. FAO. The State of Food Insecurity in the World; FAO: Rome, Italy, 2015.

18. FAO. Rome Declaration on World Food Security and World Food Summit Plan of Action; FAO: Rome, Italy, 1996.

19. Hebinck, A.; Galli, F.; Arcuri, S.; Carroll, B.; O'Connor, D.; Oostindie, H. Capturing change in European food assistance practices: A transformative social innovation perspective. Local Environ. 2018, 23, 398-413. [CrossRef]

20. Cáceres, D.; Silvetti, F.; Soto, G.; Rebolledo, W. La adopcion tecnológica en sistemas agropecuarios de pequeños productores. AGRO SUR 1997, 25, 123-135. [CrossRef]

21. Arellanes, P.; Lee, D.R. The determinants of adoption of sustainable agriculture technologies: Evidence from the hillsides of Honduras. In Proceedings of the 25th International Conference of Agriculture Economists (IAAE), Durban, South Africa, 16-22 August 2003; pp. 693-699.

22. Barrientos-Fuentes, J.C.; Berg, E. Impact assessment of agricultural innovations: A review. Econ. Rural Dev. 2013, 31, 120-130. 
23. Merino Zazo, A. Seguridad Alimentaria y Nutricional de la Agricultura Campesina de San José de Cusmapa (Nicaragua); Universidad Politécnica de Madrid: Madrid, Spain, 2012.

24. Pimentel, D. Soil erosion: A food and environmental threat. Environ. Dev. Sustain. 2006, 8, 119-137. [CrossRef]

25. Angulo, A.; Trueba, I. Las Escuelas de Campo de Agricultores (ECAs) y el análisis de sus potencialidades en los procesos de desarrollo rural y combate del hambre. El caso de la ECA Mamey (Nicaragua). In El fin del Hambre en 2025: Un Desafío para Nuestra Generación; Trueba Jainaga, I., Ed.; MUNDI-PRENSA LIBROS, S.A.: Madrid, Spain, 2006; pp. 343-390.

26. Dantsis, T.; Douma, C.; Giourga, C.; Loumou, A.; Polychronaki, E.A. A methodological approach to assess and compare the sustainability level of agricultural plant production systems. Ecol. Indic. 2010, 10, 256-263. [CrossRef]

27. Holling, C.S. Resilience of ecological systems. Annu. Rev. Ecol. Syst. 1973, 4, 1-23. [CrossRef]

28. Allen, T.; Prosperi, P.; Cogill, B.; Padilla, M.; Peri, I. A Delphi Approach to Develop Sustainable Food System Metrics; Springer: Dordrecht, The Netherlands, 2018; ISBN 1120501818658.

29. López-Ridaura, S.; Masera, O.; Astier, M. Evaluating the sustainability of complex socio-environmental systems the MESMIS framework. Ecol. Indic. 2002, 35, 135-148. [CrossRef]

30. Bell, S.; Morse, S. Towards an understanding of how policy making groups use indicators. Ecol. Indic. 2013, 35, 13-23. [CrossRef]

31. Rodriguez Osuna, J. Métodos de muestreo; Cuadernos metodológicos; Centro de Investigaciones Sociológicas: Madrid, Spain, 1991; ISBN 9788474761573.

32. Morales Vallejo, P. Tamaño Necesario de la Muestra: ¿Cuántos Sujetos Necesitamos?; Universidad Pontificia de Comillas: Madrid, Spain, 2012.

33. FAO. Why Invest in Sustainable Mountain Development?; FAO: Rome, Italy, 2011.

34. Pereira Vilchez, R.S.; Navas Morales, N.M.; Socorro Mora, N. Caracterización De 15 Municipios Pobres De Nicaragua; FIDEG: Managua, Nicaragua, 2012.

35. Monachon, D.; Gonda, N. Liberalización de la propiedad versus territorios indígenas en el norte de Nicaragua: El caso de los chorotegas; Coalición Internacional para el Acceso a la Tierra: Roma, Italia, 2011.

36. Gutiérrez Palacios, N.D. Caracterización del fotoperiodismo y agromorfología de 14 variedades de sorgo millón (Sorghum bicolor [L] Moench) en tres épocas de siembra en CNIA, Managua; Universaidad Nacional Agraria. Facultad de Agronomía: Lima, Peru, 2004.

37. Arnés Prieto, E.; Marín González, O.; Merino Zazo, A.; Hernández Díaz-Ambrona, C.G. Evaluación de la sostenibilidad de la agricultura de subsistencia en San José de Cusmapa, Nicaragua. Rev. Española Estud. Agrosociales y Pesq. 2013, 236, 171-197.

38. Vivas Viachica, E.; Herrera Ampie, J.d.C.; Avilés Sequeira, A. Evaluación del impacto en seguridad alimentaria del proyecto escuelas de campo (ECAs), dirigido a pequeñas familias campesinas de las comunidades el Terrero y el Mamey del municipio de San José de Cusmapa, Madriz. La Calera 2010, 10, 62-68.

39. Ericksen, P.J. Conceptualizing food systems for global environmental change research. Glob. Environ. Chang. 2008, 18, 234-245. [CrossRef]

40. Arnés, E.; Antonio, J.; Del Val, E.; Astier, M. Sustainability and climate variability in low-input peasant maize systems in the central Mexican highlands. Agric. Ecosyst. Environ. 2013, 181. [CrossRef]

41. Vandermeer, J.; van Noordwijk, M.; Anderson, J.; Ong, C.; Perfecto, I. Global change and multi-species agroecosystems: Concepts and issues. Agric. Ecosyst. Environ. 1998, 67, 1-22. [CrossRef]

42. FAO. Energy-Smart Food for People and Climate; FAO: Rome, Italy, 2011.

43. Astier, M.; Speelman, E.N.; López-Ridaura, S.; Masera, O.R.; Gonzalez-Esquivel, C.E. Sustainability indicators, alternative strategies and trade-offs in peasant agroecosystems: Analysing 15 case studies from Latin America. Int. J. Agric. Sustain. 2011, 9, 409-422. [CrossRef]

44. Masera, O.R.; Astier, M.; López-Ridaura, S. Sustentabilidad y manejo de recursos naturales: El marco de evaluación Mesmis; Mundi-Prensa, GIRA: Pátzcuaro, Mexico, 1999.

45. López-Ridaura, S.; Van Keulen, H.; Van Ittersum, M.K.; Leffelaar, P.A. Multiscale Methodological Framework to Derive Criteria and Indicators for Sustainability Evaluation of Peasant Natural Resource Management Systems. Environ. Dev. Sustain. 2005, 7, 51-69. [CrossRef] 
46. Pellegrini, L.; Tasciotti, L. Crop diversification, dietary diversity and agricultural income: Empirical evidence from eight developing countries. Can. J. Dev. Stud. Rev. Can. D'études du Développement 2014, 35, 211-227. [CrossRef]

47. Treminio Torres, J.C. Canasta Básica en Nicaragua: Definición y Metodología; Banco Central de Nicaragua: Managua, Nicaragua, 2013.

48. Alarcón-Cháires, P. Ecología y transformación campesina en la meseta P’urhépecha: Una tipología socio-ecológica de productores rurales de Nahuatzen, Michoacán; Universidad Michoacana de San Nicolás de Hidalgo, Secretaría de Difusión Cultural y Extensión Universitaria: Morelia, Mexico, 2001.

49. Beebe, S.E.; Rao, I.M.; Blair, M.W.; Acosta-Gallegos, J.A. Phenotyping common beans for adaptation to drought. Front. Physiol. 2013, 4, 1-20. [CrossRef] [PubMed]

50. FAO-PESA. Centroamérica en Cifras. Datos de Seguridad Alimentaria y Nutricional. 2013. Available online: http:/ / www.fao.org/3/a-at771s.pdf (accessed on 16 November 2015).

51. FAO. Estadísticas de Seguridad Alimentaria y Nutricional. Available online: http://www.fao.org/economic/ ess/ess-fs/fs-data/ess-fadata/es/ (accessed on 16 November 2015).

52. FAO. Dietary Protein Quality Evaluation in Human Nutrition; FAO: Rome, Italy, 2013.

53. FAO. Food Security Indicators. Available online: http://www.fao.org/economic/ess/ess-fs/indicadoresde-la-seguridad-alimentaria/es / (accessed on 16 November 2015).

54. FAO. Crop Prospects and Food Situation; FAO: Rome, Italy, 2008.

55. INIDE-MAGFOR. IV Censo Nacional Agropeciario. Departamento de Madriz y sus Municipios; INIDE-MAGFOR: Managua, Nicaragua, 2013.

56. Moctezuma-Malagón, A.; González-Esquivel, C.E.; De la Lanza-Espino, G.; González-Rebeles Islas, C. A methodology for evaluating the sustainability of inland wetland systems. Aquac. Int. 2008, 16, 525-537. [CrossRef]

57. Wu, N.; Ismail, M.; Joshi, S.; Yi, S.; Shrestha, R.M.; Jasra, A.W. Livelihood diversification as an adaptation approach to change in the pastoral Hindu-Kush Himalayan region. J. Mt. Sci. 2014, 11, 1342-1355. [CrossRef]

58. CEPAL; FAO; IICA. Perspectivas de la agricultura y del desarrollo rural en las Américas. Una mirada hacia América Latina y el Caribe 2014; CEPAL: Santiago, Chile; FAO: Rome, Italy; IICA: San José, Costa Rica, 2014.

59. Salcedo, S.; Guzmán, L. Agricultura familiar en América Latina y el Caribe. Recomendaciones de Politica; FAO: Santiago, Chile, 2014.

60. OECD. Adoption of Technologies for Sustainable Farming Systems. In Adoption of Technologies for Sustainable Farming Systems; OECD: Wageningen, Holland, 2001; p. 149.

61. Taylor, P.; Mishra, A.; Kumar, P.; Noble, A. Assessing the potential of SRI management principles and the FFS approach in Northeast Thailand for sustainable rice intensification in the context of climate change. Int. J. Agric. Sustain. 2013, 11, 37-41.

62. Ruiz, D.M.; Martinez, J.P.; Figueroa, A. Sustainable agriculture in high mountain ecosystems. Biotecnología en el Sector Agropecuario y Agroindustrial 2015, 13, 129-138.

63. Vien, T.D.; Dung, N.V.; Dung, P.T.; Lam, N.T. A Nutrient Balance Analysis of the Sustainability of a Composite Swiddening Agroecosystem in Vietnam's Northern Mountain Region. Southeast Asian Stud. 2004, 41, 491-502.

64. Astier, M.; García-Barrios, L.; Galván-Miyoshi, Y.; González-Esquivel, C.E.; Masera, O.R. Assessing the Sustainability of Small Farmer Natural Resource Management Systems. A Critical Analysis of the MESMIS Program (1995-2010). Ecol. Soc. 2012, 17, 25. [CrossRef]

65. Srivastava, P.; Singh, R.; Tripathi, S.; Raghubanshi, A.S. An urgent need for sustainable thinking in agriculture-An Indian scenario. Ecol. Indic. 2016, 67, 611-622. [CrossRef]

66. Wang, C.; Zhang, Y.; Yang, Y.; Yang, Q.; Kush, J.; Xu, Y.; Xu, L. Assessment of sustainable livelihoods of different farmers in hilly red soil erosion areas of southern China. Ecol. Indic. 2016, 64, 123-131. [CrossRef]

67. Baiphethi, M.N.; Jacobs, P.T. The contribution of subsistence farming to food security in South Africa. Agrekon 2009, 48, 459-482. [CrossRef]

68. Isakson, S.R. No hay ganancia en la milpa: The agrarian question, food sovereignty, and the on-farm conservation of agrobiodiversity in the Guatemalan highlands. J. Peasant Stud. 2009, 36, 725-759. [CrossRef]

69. Morris, K.S.; Mendez, V.E.; Olson, M.B. “Los meses flacos”: Seasonal food insecurity in a Salvadoran organic coffee cooperative. J. Peasant Stud. 2013, 40, 423-446. [CrossRef] 
70. UNDP. Human Development Report; UNDP: New York, NY, USA, 1990.

71. Binnendijk, E.; Dror, D.M.; Gerelle, E.; Koren, R. Estimating Willingness-to-Pay for health insurance among rural poor in India by reference to Engel's law. Soc. Sci. Med. 2013, 76, 67-73. [CrossRef] [PubMed]

(c)

(C) 2018 by the authors. Licensee MDPI, Basel, Switzerland. This article is an open access article distributed under the terms and conditions of the Creative Commons Attribution (CC BY) license (http:/ / creativecommons.org/licenses/by/4.0/). 